\title{
The future of legislated minimum wages in South Africa: Legal and economic insights
}

\section{Elsabe Huysamen}

$L L M$

Lecturer, Department of Mercantile \& Labour Law, University of the Western Cape

\section{OPSOMMING}

Die toekoms van wetlik-gereguleerde minimumlone in Suid-Afrika:

Regs- en ekonomiese insigte

\begin{abstract}
Werkloosheid- en gepaardgaande armoedevlakke in Suid-Afrika is uiters hoog. Selfs waar persone permanent werk, is sommige lone so laag dat die individue nie in 'n finansiële posisie is om basiese lewenskostes te finansier nie. Armoede, en gepaardgaande ongelykheid, bly 'n groot probleem in Suid-Afrika, veral gegewe die Grondwet se beskerming van die reg tot menswaardigheid en gelykheid vir almal. Suid-Afrika is egter nie uniek in hierdie opsig nie. Dit is 'n algemene tendens dat middel-inkomste lande dit moeilik vind om te kompeteer met lae-inkomste, lae-lone lande, terwyl hulle terselfdertyd sukkel om te kompeteer met gevorderde en hoëinkomste lande.
\end{abstract}

Werkgewers en vakbonde regoor Suid-Afrika ontmoet mekaar jaarliks om die onderhandelingstafel om onder andere basiese diensvoorwaardes, soos basiese lone, te bespreek. Indien die partye nie tot ooreenkoms kan kom in die onderhandelingsproses nie, kan dit lei tot stakings. Daar is egter 'n verskeidenheid opinies vanuit die regs wêreld en die ekonomiese arenas rakende die vlakke wat minimumlone behoort te handhaaf.

\begin{abstract}
Alhoewel geen klinkklaar gevolgtrekking bereik word nie, bespreek die artikel onder andere die volgende kwessies: of dit prakties en realisties is om minimumlone deur middel van wetgewing te reguleer in Suid-Afrika; watter impak wetlik-gereguleerde minimumlone moontlik kan hê op die Internasionale Arbeidsvereniging se Billike Werksagenda; en die moontlike formaat wat 'n suksesvolle wetlik-gereguleerde minimumloon-stelsel moontlik kan aanneem.
\end{abstract}

\section{Introduction}

During the mid-1950s Nobel Memorial Prize in Economic Sciences recipient, Sir W A Lewis, proposed a new theoretical model of economic development for developing countries. This model was premised on the assumptions that, first, there was an unlimited supply of labour in most developing countries and, secondly, as the modern industrial sector in such countries developed, these growing economies would be able to 
absorb any labour surplus. ${ }^{1}$ Rising high unemployment levels globally, however, would suggest inaccuracies in this model. Paradoxically, with unemployment levels on the rise internationally, statistics indicate that over the last 40 years the average real-unit labour costs in South Africa has increased twice as fast as that of the 30 wealthiest Organisation for Economic Co-operation and Development (OECD) ${ }^{2}$ countries. This is

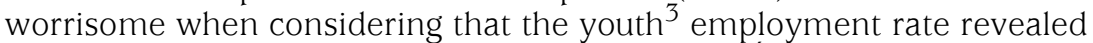
a drop from $16.2 \%$ in 2000 to $14.6 \%$ in 2008.4 It might perhaps be argued that these and other similar statistics suggest that "[a] policy of good jobs in principle, but no jobs in practice, might assuage our consciences, but it is no favor to its alleged beneficiaries". 5

Apart from rising unemployment levels, poverty levels of those who do have jobs in South Africa are also alarmingly high. While seemingly at odds, working poverty is the situation where working employees continue to earn such low wages that they are unable to meet basic living needs. ${ }^{6}$ High poverty levels, and the inherent inequality that comes with it, remain a great cause of concern, whether viewed from economic sustainability, social justice, or basic adherence to Constitutional ${ }^{7}$ imperatives such as dignity and equality for all. ${ }^{8}$ The situation in South Africa is nevertheless not unique. Many developing countries find themselves in a so-called middle-income trap. These countries need to find ways of bridging the gap between, on the one hand, an economicgrowth model based on the exploitation of low-cost labour as a means of gaining a competitive advantage, and on the other, an economic-growth model largely dependent on capital investment and high productivity. However, bridging this gap in an increasingly globalised trading environment remains problematic. Middle-income countries find it difficult to compete with low-income, low-wage economies in

1 Lewis Economic Development with Unlimited Supplies of Labour as discussed in Chen et al Supporting Workers in the Informal Economy: A Policy Framework (Working paper on the informal economy 2002 ILO Employment Sector) 1 .

2 THE OECD is an intergovernmental economic organisation founded in 1962 , with a member base of 35 countries currently.

3 For purposes of these statistics, youth is regarded as individuals between the ages of 15 and 24.

4 Trading Economics 2011 available at www.tradingeconomics.com, as referenced in Cohen \& Moodley "Achieving 'Decent Work' in South Africa" 2012 PER 323.

$5 \quad$ Krugman In Praise of Cheap Labor: Bad jobs at bad wages are better than no jobs at all available at http://web.mit.edu/krugman/www/smokey.html (accessed 2012-08-09).

6 https://www.dailymaverick.co.za/article/2016-08-11-op-ed-a-national-mini mum-wage-for-south-africa-the-path-to-economic-growth/\#.WqUKgChuZdh (accessed 9 June 2018).

7 In terms of the Constitution of South Africa, 1996.

8 https://mg.co.za/article/2016-12-12-00-a-national-minimum-wage-is-apowerful-tool-to-break-the-poverty-cycle (accessed 2018-06-09). Constitution s 1; s 2 of the Constitution further states that the Bill of Rights "... enshrines the rights of all people in our country". 
manufactured exports on the one side, and advanced economies in highskill innovations on the other. ${ }^{9}$

The above does not bode well for employees when it comes to minimum wages. For most employees, demands around increased conditions of employment, particularly increases in wages, are simply born out of their need for financial survival or for increased financial stability. Employers and trade unions across various sectors in South Africa periodically engage in negotiations on issues of terms and conditions of employment, most notably wages. Where the parties are unable to reach agreement the Constitution of South Africa, 1996, assisted by the Labour Relations Act 66 of 1995 (LRA), provide employees with the right to strike and employers with the right to lockout. Far too often such industrial action unfortunately turns into violent displays of power (or perhaps only perceived power), even at times resulting in loss of life such as was the case in the Marikana incident of 2012 (discussed below). A contentious issue often raised in the South African context is whether, given South Africa's social and economic climate, employee demands for wage increases are reasonable and viable. This question is partly driven by the trend to demand wage increases far in excess of the annual inflation rate.

Although no definite conclusion is likely to be reached, this article will attempt to address the following: whether legislated minimum wage levels in South Africa is a realistic, and in fact workable, option; what impact implementing legislated minimum wage levels might have on achieving the International Labour Organisation's (ILO) decent work agenda, ${ }^{10}$ and the form that any successful legislated minimum wage level system should take.

\section{Labour Market Regulation}

During the mid-19th century economists in the United States of America (USA) sought to justify vast income inequalities between employees by relying on what at the time was referred to as the marginal-productivity theory. This theory was predicated on the existence of an identifiable link between higher income and higher productivity. A higher income was directly indicative of an employee's greater contribution to society. Not surprisingly this theory was particularly cherished by the rich. ${ }^{11}$ During the latter part of the 19th century, globalisation, as understood in the

9 Deakin "Labour Law, Economic Development, and the Minimum Wage: Comparative Reflections on the South African Debate" 2017 ILJ 10.

10 Refer to the discussion on the ILO's decent work agenda in par 4.1 below.

11 Stiglitz of the $1 \%$, by the $1 \%$, for the $1 \%$ available at http://www.vanityfair. $\mathrm{com} /$ society/features/2011/05/top-one-percent-201105 (accessed 2012-0605). 
modern sense, ${ }^{12}$ came to the forefront as a result of strides made in technological innovation which increased the exchange of knowledge, trade and capital on an international level. ${ }^{13}$

Subsequent to the international integration of markets and people brought about by the internationalisation of investment and colonial expansion, and the ultimate onset of the modern understanding of globalisation, businesses were suddenly, and continue to be, exposed to intense competition on national and international levels. Businesses are constantly under pressure to adjust their operations and labour forces to meet fluctuations in demand and progress in productivity. ${ }^{14}$ In an attempt to meet these rising demands, businesses often look towards a reduction in worker wages, or lower levels of wage increases, as a means of economic growth and survival. Correlations between the onset of globalisation and rising demands for increased minimum wages were therefore to be expected. This leads one to ask whether increasinglycompetitive labour markets should perhaps not be regulated by designated outside forces, such as labour laws.

Labour market policies and regulation remain a highly contested area, with many supporters of both regulation and non-regulation of labour markets respectively. Those in favour of an interventionist approach advocate for regulation, mainly through legislation, aimed towards assisting a poor and vulnerable workforce. Proponents of this approach regard labour laws as any state-recognised labour rights and standards aimed at improving the quality of working lives and bargaining power of workers. ${ }^{15}$ Supporters of labour market regulation further argue that labour markets, particularly those of developing countries, are highly imperfect when no dedicated intervention takes place. One example generally used is the frequent power imbalances observed between employers and workers. It is argued that an unregulated market potentially increases the risk of exploitation and unfair treatment of

12 Reference to "... globalisation, as understood in modern times ..." should be understood in the context of certain scholars that view globalisation as a concept which originated as far back as 1492 and 1498 already when Christopher Colombus and Vasco da Gama discovered the Americas and sailed around the horn of Africa respectively - as example, see O'Rourke \& Williamson When Did Globalization Begin? (Working Paper 76322000 National Bureau of Economic Research) available at www.nber.org/papers/ w7632 (accessed 2018-05-31); also available at O'Rourke \& Williamsnon "When Did Globalization Begin?" 2002 European Review of Economic History 23-50.

13 The Economist When did globalisation start? (2013-09-23) available at https: //www.economist.com/free-exchange/2013/09/23/when-did-globalisationstart (accessed 2018-05-30).

14 Auer, Berg \& Cazes "Balancing Flexibility and security: The role of labour market policies and institutions" 2007-2008 Tilburg Law Review 49.

15 Marshall, Howe \& Fenwick Labour Law and Development: Creating and Enabling Regulatory Environment and Encouraging Formalisation (Paper 2009 Conference of the Regulating for Decent Work Network ILO) 4 available at http://www.ilo.org/legacy/english/protection/travail/pdf/rdw paper27a.pdf (accessed 2012-08-27). 
workers, which in turn impacts negatively on human development and growth. ${ }^{16}$ Regulation through legislative intervention is therefore argued. Otto Kahn-Freund summarised the main rationale for labour law as “... a countervailing force to counteract the inequality of bargaining power which is inherent and must be inherent in the employment relationship". ${ }^{17}$ It is argued that labour market regulation through rules and controls in respect of working conditions could significantly reduce exploitation of workers, which in turn impacts on overall worker productivity. ${ }^{18}$ Increased worker productivity it is held contributes towards market competitiveness and growth, which reduces the need for cost-cutting measures, such as wage decreases and poorer working conditions. ${ }^{19}$ Protection against exploitation also significantly contributes towards the achievement of the ILO's decent work objective and constitutional imperatives, including the rights to dignity and fair labour practises. ${ }^{20}$

The true effectiveness of legal rules and policies is nevertheless often questioned, despite how effective they might look on paper. The question is largely based on the view that legal rules and policies often are not practically implemented in the informal economy and have little benefit to these workers, largely as a result of non-adherence by employers and a lack of enforcement. Considering the large number of workers employed in the informal economy where work opportunities are more readily available for poor and unskilled workers, particularly in developing countries, questions around effectiveness and practicality are well-founded. ${ }^{21}$

On the other hand, supporters of the neoclassical school of thought advocate the increased deregulation of labour markets with a view to rendering them more efficient. ${ }^{22}$ It is argued that reforms of the legislative regime are required in order to enhance workforce flexibility. The argument largely is based on the view that workforce flexibility will contribute to increased market competitiveness, economic growth and ultimately employment opportunities. It is said that a regulatory approach, through protective legislation as example, often results in the

16 Deshingkar Extending labour inspections to the informal sector and agriculture (Working paper nr 1542009 Chronic Poverty Research Centre) 6.

17 Benjamin Labour Market Regulation: International and South African Perspectives (Paper 2005 Employment \& Economic Policy Research Programme Human Sciences Research Council) 5.

18 Deshingkar 4.

19 Deshingkar 6.

20 Respectively protected within the Bill of Rights in ss 10 and 23 of the Constitution. These rights should be read in conjunction with s 1 (a) of the Constitution which provides that "The Republic of South Africa is one, sovereign, democratic state founded on the following values: (a) Human dignity, the achievement of equality and the advancement of human rights and freedoms ...." As to the ILO's decent work agenda, see the discussion in 4.1 below. Also see Deshingkar 6.

21 Deshingkar 4.

22 Deshingkar 4. 
misallocation of available resources. Regulation leads to the absence of any real flexibility to adjust wages freely to the marginal productivity of labour; a regulatory approach often prevents labour markets from spontaneously adjusting to acute economic changes and shocks; and regulation has the potential to reduce profits, which in turn could result in the reduction of investments and, ultimately, market growth. ${ }^{23}$

While arguments in favour of regulation and deregulation are interesting, in the South African context the discussion has been rendered mostly academic over recent years. Since the adoption of the Constitution in the 1990s, labour market regulation is rather firmly embedded into South African employment law by virtue of various statutes and related pseudo-legislation such as sectoral determinations. Labour market regulation largely is divided into the following subcategories: minimum conditions of employment; collective bargaining and worker participation; dispute resolution and adjudication; promoting equality in the workplace; skills development and placement within the labour market; and employment linked social security. ${ }^{24}$ Legislated minimum wages are regarded as a form of minimum conditions of employment.

\section{Arguments in Favour of and Against Legislated Minimum Wage Levels as a Form of Labour Market Regulation}

"But if a young adult cannot produce enough of value to justify being paid a living wage, nothing we do to the minimum wage will help. He, the institutions which trained him and the society in which he lives, have far bigger problems." (Tim Harford) ${ }^{25}$

Disagreement amongst commentators and stakeholders, from both economic and legal fields, on the feasibility and impact of minimum wages as a form of labour market regulation on employment levels and economic growth is nothing new. In considering labour laws and economic principles in the same context, two inseparable views emerge. The first view holds that employees and employers play a complementary role in production and the running of a successful business. The second view holds that employees and employers,

23 Deshingkar 6.

24 Benjamin $3-4$.

25 FT Magazine Can the minimum wage create jobs? (2012-01-13) available at http://www.ft.com/cms/s/2/6e61f3d6-3c05-11 e1-bb39-00144feabdc0.html\# axzz2LYq9Uvfl (accessed 2013-02-21). 
subsequent to the completion of the production process, compete with one other over the benefits brought about through production. ${ }^{26}$ In general there however seems to be agreement that labour laws must be for the good of society at large, and ensuring the availability of sufficient and decent jobs remains a collective responsibility. ${ }^{27}$

It is however often also argued that legislated minimum wage levels do not only regulate employment relationships, but the operation of the labour market in general as well. ${ }^{28}$ As example, during the 1980s it was widely accepted that labour laws could be implemented as instruments of economic policy to, for instance, control inflation. ${ }^{29}$ Consequently modern labour law has been argued to have four main objectives: the promotion of allocative and productive efficiency and economic growth; macroeconomic management by achieving wage stabilisation, high employment levels and international competitiveness; establishing and protecting fundamental rights; and redistributing wealth and power in the employment context. ${ }^{30}$ Labour market regulation can therefore be used to enhance the employment conditions of workers, such as higher minimum wage levels. ${ }^{31}$ In turn minimum wage levels potentially impact on three macroeconomic variables: demand for goods and the growth of the economy; employment levels; and inflation. 32

Arguments against legislated minimum wage levels range from those arguing against implementing any form of legislated minimum wages, to those observing that current minimum wage levels in South Africa are simply too high and therefore unattainable. It is often argued by these critics that the very employees such policies are said to assist may in fact fall prey to growing prejudice and harm as a result of these policies. In turn, proponents of legislated minimum wages remain firm in their view that increased wages play an important role in moving people out of poverty. Arguments by minimum wage supporters have largely been

26 Economic implications of labour and labour-related laws on MSEs: A quick review of the Latin American experience (Working Paper No. 312009 ILO Employment Sector) 3 available at http://www.ilo.org/wcmsp5/groups/pub lic/@ed_emp/@emp_ent/documents/publication/wcms_115966.pdf (accessed 2012-08-27).

27 Antoine "Rethinking Labour Law in the New Commonwealth Caribbean Economy: A Framework for Change” 2011 Comparative Labor Law \& Policy Journal 354.

28 Benjamin 2.

29 Benjamin 5.

30 Klare K "The Horizons of Transformative Labour and Employment Law" in Conaghan, Fischl \& Klare (eds) Labour Law in an Era of Globalisation: Transformative Practices and Possibilities (2002) as referenced in Benjamin 5.

31 Benjamin 5.

32 Eyraud \& Saget The Fundamentals of Minimum Wage Fixing (2005 ILO) 47. 
premised on the ideal of improved quality of life for low income and vulnerable workers. ${ }^{33}$ Finally, it has also been argued that in light of trade unions' declining bargaining power, especially when faced with high unemployment rates, legislated minimum wage levels play an increasingly important role in the protection of workers. ${ }^{34}$

Speaking at the release of his annual South African Employment Report during May 2012, economist Mike Schussler was of the opinion that " $[t]$ he ugly truth in South Africa is that unskilled and semiskilled workers are being overpaid, which contributes to keeping other people out of the job market". 35 This statement, however, could be criticised for its seemingly flawed premise, that is, that labour should be kept cheap, and that the job market referred to seemingly hint towards a market that exists for cheap and unskilled, or at best semi-skilled, labour. Furthermore, a fundamental question the statement fails to address is the reason why workers are still in positions of being unskilled or semiskilled. At the time the Congress of South African Trade Unions (Cosatu) also refuted the statement. Cosatu argued that Schussler had abused the statistical data used as basis for his report, the information on which his views were based was incorrect, and that he had misconceived the principle of purchasing power parity in South Africa. ${ }^{36}$

Those opposing legislated minimum wages often argue that unemployment levels potentially stand to rise as a result of significant increases in minimum wage levels. ${ }^{37}$ In a country such as South Africa, where unemployment levels are already alarmingly high, a further rise in such levels would in turn deprive individuals of an income, as well as the gaining of work experience which could in the long run affect earning ability. ${ }^{38}$ With limited employment opportunities already a reality, it is argued that workers who are regarded as being overpaid (generally lowskilled workers) through, eg, legislated minimum wage levels, prevent individuals who are willing to earn less from entering meaningful employment. As such it is argued that downward wage flexibility is important in achieving sustainable levels of employment and growth. ${ }^{39}$

33 Thomas Basic Economics: A Common Sense Guide to the Economy (2007) as referenced in Hutchison "Waging War on 'Unemployables'? Race, Low-wage work and Minimum Evidence: The New Evidence" 2011 Hofstra Labor \& Employment Law Journal (Hofstra Lab. \& Emp. L. J.) 26.

34 Labour Administrations and National Labour Policies: Current Challenges, Practices and Policies (2009 ILO Social Dialogue Sector) 11 available at http:/ /www.ilo.org/wcmsp5/groups/public/--_ed_dialogue/--_lab_admin/documents /publication/wcms_123787.pdf (accessed 2012-08-27).

35 “Unskilled workers 'paid too much' in SA" Business Day Live (2012-05-07) available at http://www.bdlive.co.za/articles/2012/05/07/unskilled-workerspaid-too-much-in-sa;jsessionid = A2A980CCEB576A9EE6720B3BD6701 AB A.present2.bdfm (accessed 2013-02-21).

36 Cosatu A response to Mike Schussler: Busting Schussler's myths, exposing white excess available at http://www.cosatu.org.za/show.php?ID $=6132$ (accessed 2013-02-21).

37 Thomas as referenced in Hutchison 2011 Hofstra Lab. \& Emp. L.J. 26.

38 Thomas as referenced in Hutchison 2011 Hofstra Lab. \& Emp. L. J. 26.

39 Deshingkar 6. 
It has to be noted however that while the effect of minimum wages on employment levels has been researched in developed countries, very few similar studies have been undertaken in developing economies thus far. Consequently much less is known about the impact of legislated minimum wages on employment levels in emerging economies. ${ }^{40}$ And of those studies in respect of developing countries, very few have found sufficient empirical evidence to show that a rise in minimum wages had any significant effects on the employment levels. ${ }^{41}$ In the South African context, reports and statistics on employment growth and reduction in sectors covered by sectoral determinations indicate no significant reduction in employment levels subsequent to the implementation of minimum wages in these sectors, with some even indicating a slight increase in employment levels. ${ }^{42}$

It is further argued that strictly-legislated minimum wage levels, especially those on the higher end of the spectrum, increase the financial burden on companies, many of which are already struggling under ongoing difficult economic conditions. ${ }^{43}$ Part of the increased financial burden experienced by businesses is higher production costs. While of course varying between different sectors, on average labour costs remain a significant component of production costs. ${ }^{44}$ Some economists who argue against minimum wages, or wages which are set too high, rely on statistics which indicate that while internationally production costs have decreased on average, these costs in South Africa have consistently been

40 Broecke, Forti, Vandeweyer The effect of minimum wages on employment in emerging economies: a literature review 2 available at http://national minimumwage.co.za/wp-content/uploads/2015/09/0221-Effect-of-Minimum -Wages-on-Employment-in-Emerging-Economies-A-Literature-Review.pdf (accessed 2018-06-09).

41 As example see Baek \& Park "Minimum wage introduction and employment: Evidence from South Korea" 2016 Economics Letters; Addison, Blackburn \& Cotti "Do minimum wages raise employment? Evidence from the U.S. retail-trade sector" 2009 Labour Economics; Broecke, Forti \& Vandeweyer The effect of minimum wages on employment in emerging economies: a literature review available at http://nationalminimum wage.co.za/wp-content/uploads/2015/09/0221-Effect-of-Minimum-Wageson-Employment-in-Emerging-Economies-A-Literature-Review.pdf (accessed 2018-06-09).

42 Benjamin 29 - 30. See also Addressing the Plight of Vulnerable Workers: The Role of Sectoral Determinations (2010 Department of Labour) available at http://www.labour.gov.za/DOL/downloads/documents/useful-documents/bas ic-conditions-of-employment/The \% 20role \% 20of \% 20Sectoral \% 20Determi nations.pdf (accessed 2018-05-31); Sectoral Determination 7 of Domestic Workers: A catalyst for change? available at http://www.polity.org.za/article/ sectoral-determination-7-of-domestic-workers-a-catalyst-for-change-2013-11 -21 (accessed 2018-05-31); Addison, Blackburn \& Cotti "Do minimum wages raise employment? Evidence from the U.S. retail-trade sector" 2009 Labour Economics 407.

43 "Cosatu set to push for minimum wage policy" Business Day (2012-06-06) available at http://www.businessday.co.za/articles/Content.aspx?id =1734 28 (accessed 2012-06-06).

44 "Cosatu like French beet farmers on SA 'low wages'” Business Day (201205-21) available at http://www.businessday.co.za/articles/Content.aspx?id= 172198 (accessed 2012-06-06). 
on the rise. This remains of concern in a globalised economy where international competition remains rife and cheaper foreign labour remains freely available. Consequently South Africa is rendered less competitive on an international level. ${ }^{45}$ Yet, experiences from across Europe in cutting labour costs to lower production costs seem to suggest a different reality.

In response to increasing economic pressures many European governments implemented overall worker rights reductions as one measure to bring down labour costs. Not surprisingly cutting of wages and decreases in other employment benefits, such as unemployment benefits, were met with much hostility by both workers and trade unions. ${ }^{46}$ Such an approach resulted in a noticeable decrease in disposable household income, which led to a decline in consumer spending. This decline in consumer spending in turn negatively impacted on economic growth. ${ }^{47}$ The lowering of wage levels also negatively impacted on the living standards of workers and consequently the ILO's decent work agenda. ${ }^{48}$

Turning now to arguments raised by those in support of minimum wage levels, one argument with a lot of support is that, even if it was accepted that legislated minimum wage levels might result in some short-term employment loss following implementation, increased employment levels in the long run were likely to be observed. This might emerge in one of two ways. First, low wage levels might result in a socalled low-productivity trap which hinders job growth. A low-productivity trap is where employers fail to invest in their workers through, for example, payment of proper wages, training initiatives and other retention efforts, which measures are often associated with an increase in aggregate workplace productivity levels. Where investment in workers are lacking, low productivity levels are likely to be observed, and consequently business profit levels stand to be negatively affected. This in turn limits a business's potential for growth and further employment creation. Second, legislated minimum-wage policies might also be utilised to correct market failures. Such policies could guard against wage deflation and a resultant decline in aggregate consumer spending. It is argued that, in theory at least, higher wages for employees should lead to increased consumer spending which in turn contributes towards

45 "Unskilled workers 'paid too much' in SA" Business Day (2012-05-07) available at http://www.businessday.co.za/articles/Content.aspx?id $=1710$ 83 (accessed 2012-06-05).

46 Consider for example the situations in Greece and Italy during 2012.

47 "The crisis, golden opportunity for employers" Frankfurter Rundschau (2012-03-23) available at http://www.presseurop.eu/en/content/article/ 1678031 -crisis-golden-opportunity-employers (accessed 2012-08-27).

48 Labour Administrations and National Labour Policies: Current Challenges, Practices and Policies (2009 ILO Social Dialogue Sector) 10 available at http:/ /www.ilo.org/wcmsp5/groups/public/---ed_dialogue/---lab_admin/documents /publication/wcms_123787.pdf (accessed 2012-08-27). 
economic growth, and as such, job creation. ${ }^{49}$ Caution should however be taken in simply linking a raise in minimum wages with a definite rise in labour productivity. A higher wage level is but one factor in a spectrum of factors which has the potential to impact labour productivity. Other contributing factors include the scale and nature of capital investment in a country, the state of a country's training and education systems, and, perhaps less directly so, the effectiveness of a country's legal and governmental institutions. ${ }^{50}$ Consequently, and this cannot be overemphasised, a crucial focus area towards ensuring a country's ability to sustain long term economic growth and prosperity should be steps taken to ensure a rise in the training and skills levels of its workforce.

The absence of reasonable legislated minimum wage levels, particularly at the level of a living wage, is likely to result in cycles of continued poverty and lack of skills. It is argued that in the absence of proper education and training, workers' earning abilities remain limited. Yet, poorly paid workers cannot afford the further training or education necessary to increase their skills and consequently their earning potential. This inevitably raises the question as to who should be responsible for ensuring that necessary education and training take place. This article supports a view that would advocate for a tripartite responsibility, ie, the responsibility should rest on employees, employers and government alike. Employers should have the responsibility to identify skills needs in the business, particularly in light of increased technology. The responsibility of government should be to, more than it does at the moment, facilitate the development of identified skills. And finally, employees should be responsible for ensuring that they subject and commit themselves to undertake further education and training. The reality however remains that poorly-paid workers continue to find themselves in a cycle of poverty and lack of further education which, without some outside intervention (such as bursaries, grants or other third-party funding), has little prospect of ending. The situations these workers find themselves in are worsened by an era of increased technological advances, which either negates the need for manpower, or requires workers to keep abreast with ever-changing technological advancements. Individuals who remain untrained, or insufficiently trained, in technological matters are effectively prevented from working in high productivity and technologically-advanced environments. ${ }^{51}$

Legislated minimum-wage levels are also justified in the context of imperfect labour markets where employees, particularly those engaged in non-unionised informal work, such as domestic workers, remain vulnerable. It is argued that legislated minimum wage levels might

49 Towards a COSATU Living Wage Conference: A NALEDI Research Report (Report 2011 COSATU) 11 available at http://www.cosatu.org.za/docs/reports 12011/naledi_research_paper.pdf (accessed 2012-08-27).

50 Deakin 2017 ILJ 8

51 Return to Social Movement Unionism partner (2011 Naledi) available at http:/ /www.naledi.org.za/index.php?option $=$ com_k2\&view $=$ item\&id $=42$ :retu rn-to-social-movement-unionism (accessed 2012-05-24). 
protect these workers against exploitation. As example, many households which employ domestic workers consider the worth of these workers to far outweigh the wages actually paid to such workers. ${ }^{52}$ Studies in fact indicate that majority of households are willing to increase domestic workers' wages rather than running the risk of losing these workers. ${ }^{53}$ Yet, domestic worker wage levels do not provide an accurate reflection of the valuable contribution these workers make, not only to the household economy, but the national economy through enabling their employers to work. By having a domestic worker taking over some household chores (most commonly cleaning, cooking, and child rearing), the employer has more free time available which could be used to generate further income. The income generated as such generally exceeds the amount in wages paid to the domestic worker. The financial benefits experienced by the employer, and even more so in the case of multiple income households, are rarely reflected in the wages paid to domestic workers. Data in fact shows that even as far back as the early 1990s, on average wages of domestic workers constituted, at best, a mere $4 \%$ of an employer's salary. ${ }^{54}$ Where minimum wages are legislatively determined it will be more difficult for employers to engage in unfair low wage competition. This is off course reliant on the premise that as long as unemployment remains rife, competition over available jobs will remain high. And this is where the opportunity is created for unscrupulous employers to lower wages and provide poorer working conditions to those individuals who remain desperate to generate any form of income. Such workers would in general also be hesitant to challenge their employers' conduct out of fear of retaliation and dismissal. ${ }^{55}$ This is of concern when considering that job security is regarded as a fundamental component of decent work. 56

While there will always remain tension between regulation and nonregulation of minimum wages, in the South African context the issue is these days largely academic. Minimum wages are already regulated on a sectoral level through sectoral determinations. Furthermore, the recently-adopted National Minimum Wage Bill ${ }^{57}$ is another step towards further embedding the regulation of minimum wages in the South African employment environment. It is arguably therefore no longer a question of whether to regulate, but rather one of how to best regulate.

52 Cosatu 201110 available at http://www.cosatu.org.za/docs/reports/2011/ naledi_research_paper.pdf (accessed 2012-08-27).

53 Cosatu 201110 available at http://www.cosatu.org.za/docs/reports/2011/ naledi_research_paper.pdf (accessed 2012-08-27).

54 Cosatu 201110 available at http://www.cosatu.org.za/docs/reports/2011/ naledi_research_paper.pdf (accessed 2012-08-27).

55 Return to Social Movement Unionism partner (2011 Naledi) available at http:/ /www.naledi.org.za/index.php?option $=$ com_k2\&view $=$ item\&id $=42:$ ret urn-to-social-movement-unionism (accessed 2012-05-24).

56 Cohen \& Moodley 2012 PER 329.

57 National Minimum Wage Bill B31 of 2017, published in GG 41257 of 17 November 2017. 


\section{Understanding Living- and Minimum Wages in a Decent Work Paradigm}

\section{International Labour Organisation's Decent Work Agenda}

The ILO's Decent Work Agenda was introduced in the late 1990s by former ILO Director-General, Juan Somavia. The ILO has expressed the Decent Work Agenda as follows:

"The goal of decent work is best expressed through the eyes of people. It is about your job and future prospects; about your working conditions; about balancing work and family life, putting your kids through school or getting them out of child labour. It is about gender equality, equal recognition, and enabling women to make choices and take control of their lives. It is about your personal abilities to compete in the market place, keep up with new technological skills and remain_healthy. It is about developing your entrepreneurial skills, about receiving a fair share of the wealth that you have helped to create and not being discriminated against; it is about having a voice in your workplace and your community. In the most extreme situations it is about moving from subsistence to existence. For many, it is the primary route out of poverty. For many more, it is about realizing personal aspirations in their daily existence and about solidarity with others. And everywhere, and for everybody, decent work is about securing human dignity. But to bridge reality and aspiration, we need to start by confronting the global decent work deficit. It is expressed in the absence of sufficient employment opportunities, inadequate social protection, the denial of rights at work and shortcomings in social dialogue. It is a measure of the gap between the world that we work in and the hopes that people have for a better life." 58

The decent work agenda acknowledges that all individuals, regardless of background, race, gender, social status, or employment and so on "have the right to pursue both their material well-being and their spiritual development in conditions of freedom and dignity, of economic security and equal opportunity" ${ }^{59}$ Poor wage levels it is argued do not adhere to the ILO's Decent Work Agenda. Decent work should encompass:

"a strategic goal for development that acknowledges the central role of work in people's lives. This includes work that is productive and delivers a fair income; provides security in the workplace and social protection for families; and offers better prospects for personal development and social integration, freedom to express concerns, opportunities to organize and participate in

58 Reducing the decent work deficit - a global challenge (2001 ILO) available at http://www.ilo.org/public/english/standards/relm/ilc/ilc89/rep-i-a.htm (accessed 2018-06-09).

59 Macnaughton \& Frey "Decent Work for all: A holistic human rights approach" 2011 American University International Law Review 449. 
decision-making, and equal opportunity and treatment for all women and men". 60

Of some significance is the fact that the ILO opted to use the concept decent work as opposed to decent employment. It appears as if the reference to work was deliberate so as to not only include workers in the formal economy, which is regarded as traditional employment in most countries, but all individuals engaged in some form of work. This approach acknowledges that there are a "variety of ways in which people contribute to the economy and society". 61

The ILO submits that there are four main factors to consider in advancing decent work principles. Firstly, it is important to highlight the ideal of worker rights at the workplace. The objective is "to ensure that work is associated with dignity, equality, freedom, adequate remuneration, social security and voice, representation and participation for all categories of workers". ${ }^{2}$ Secondly, further steps must be taken to close the gap between employment and work. The aim is to produce sufficient work opportunities for the majority of individuals and to ensure that proper and reasonable wages are paid. ${ }^{63}$ Thirdly, adequate social protection should be provided to cover a variety of contingencies and vulnerabilities, such as unemployment. ${ }^{64}$ Finally, there should be an increased focus on social dialogue. Workers' voices must be strengthened by means of proper representation, and in doing so enable workers to defend their interests, articulate concerns, and engage in negotiations and other discussions around worker rights in general. ${ }^{65}$ As a member state of the ILO, the South African government has pledged its commitment towards the achievement of decent work for all workers, and the inclusion of decent work imperatives into national development strategies. ${ }^{66}$ Minimum wage considerations arguably fit best under closing the gap between employment and work, which includes the payment of proper and reasonable remuneration.

This adherence to the ILO's decent work agenda provides at least one theory as to why governments choose to intervene in labour markets. The theory is predicated on the assumption that free and unregulated labour markets are imperfect for various reasons. Unregulated labour markets create opportunities for unscrupulous employers to abuse

60 Tackling the "decent work deficit" (ILO) available at http://wcmsq3.ilo.org/ global/about-the-ilo/newsroom/features/WCMS_071242/lang-ren/index.htm (accessed 2012-12-11), as quoted in du Toit "Extending the frontiers of employment regulation: The case of domestic employment in South Africa" 2010 LDD 4.

61 Macnaughton \& Frey 2011 American University International Law Review 449.

62 Ghai D (ed) Decent Work: Objectives and Strategies (2006 ILO) 7.

63 Ghai D (ed) 10.

64 Ghai D (ed) 14.

65 Ghai D (ed) 18.

66 Cohen \& Moodley “Achieving 'Decent Work' in South Africa” 2012 PER 320. 
workers' rights, such as the right to decent work, in an effort to limit employment costs. ${ }^{67}$ Consequently, in the absence of meaningful and effective labour regulation, the achievement of decent work for all will remain but an ideal. Workers are likely to remain subjected to an employer's sense of fairness, rather than commonly established legal norms within which the societal contributions and inherent human dignity of workers are valued. ${ }^{68}$ This is particularly of concern in societies such as South Africa where constitutional values underpin the basic rights all individuals enjoy. It is generally accepted that decent work should be approached from a holistic human rights framework - one within which individuals, families, and decent employment are all addressed.

\section{Minimum- Versus Living Wages}

It has been said that “... nearly all individuals who work or seek work do so in order to earn an income and ensure the economic well-being of themselves and their households". 69 Minimum wage levels should be distinguished from what is commonly referred to as a living wage. A living wage, narrowly seen, has been described as a minimum wage of a value that would enable a worker to live a life of determined quality when considering needs such as housing, food, utilities, transport, and health care. From a broader view, a living wage is seen as a tool to move low income and underpaid workers out of a life of poverty. This includes creating a sustainable wage income strategy which not only focuses on meeting basic living needs, but also on improving overall worker skills and employment opportunities, while at the same time reducing income inequality and poverty. ${ }^{70}$

In South Africa, Cosatu has been known for advocating that demands for living wages should form the cornerstone of any trade union's role in the fight against poverty. ${ }^{71}$ Cosatu has argued that a contract of employment between a worker and his/her employer cannot be regarded as equal or fair where "such a workman submits to work for a low wage to avoid starvation or pauperism (or something like it) for himself or his family". ${ }^{72}$ Cosatu uses the example of millions of South Africans that spend their working lives in the gold mining or commercial

67 Botero et al "The Regulation of Labor" 2004 The Quarterly Journal of Economics 3. See discussion on the ILO's decent work agenda in 3 above.

68 Blackett "Introduction: Regulating Decent Work for Domestic Workers" 2011 Canadian Journal of Women \& the Law 25.

69 Anker et al Measuring Decent Work as referenced in Cohen \& Moodley 2012 PER 327.

70 Cosatu 201113 available at http://www.cosatu.org.za/docs/reports/2011/ naledi_research_paper.pdf (accessed 2012-08-27).

71 Cosatu 20119 available at http://www.cosatu.org.za/docs/reports/2011/ naledi_research_paper.pdf (accessed 2012-08-27).

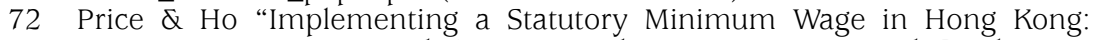 Appreciating International Experiences but Recognizing Local Conditions" 2011 Common Law World Review 105. 
agricultural industries, whilst never escaping a life of poverty because of the meagre wages earned. ${ }^{73}$ This suggests that South Africa falls short in various respects when it comes to the provision of minimum wages at levels which could be said to cater for a living wage.

The first shortcoming often highlighted is the problematic or unsuccessful structure/form that minimum wage levels take in South Africa. Rather than having one national minimum wage, unions argue that government prefers fragmented minimum wage levels in different industries and sectors. A second shortcoming highlights the appropriate level of minimum wages to be paid. Cosatu argues that minimum wage levels should be based on the ideal of a living wage for all, whereas in South Africa there is no clear relation between existing minimum wage levels and what would be regarded as a minimum living wage. It is argued that most South Africans who work for a minimum wage continue to live in poverty. The third shortcoming can be found in the absence of a so-called solidaristic approach. Those who argue for minimum wage levels which are reflective of a living wage advocate that minimum wage levels should be constantly increased, whilst at the same time decreasing gaps in wage levels. ${ }^{74}$ Finally, it is argued that the relationship between a national minimum wage and collective bargaining should be regarded as complementary in nature. A national minimum wage level should set the minimum level below which no worker's wage may fall, with collective bargaining used to increase the minimum wage floor in different industries and regions. ${ }^{75}$

\section{Minimum Wages in South Africa}

Employee rights in South Africa as a topic is nothing new and has been the subject of debate for generations. Over the years many factors have influenced this debate. One such factor is globalisation and the access it provided to cheaper foreign labour with a consequent decrease in local working conditions. ${ }^{76}$ Wage demands and wage levels specifically came under the spotlight during the global financial crisis of 2007/2008, which resulted in alarmingly high levels of unemployment. Another topic often encountered in employee rights' debates is the substantial informal

\section{Chen 12.}

74 The 2014 amendments to the EEA have introduced a provision to address the principle of equal pay for work of equal value - s 6(4) now stipulates that “[a] difference in terms and conditions of employment between employees of the same employer performing the same or substantially the same work or work of equal value that is directly or indirectly based on any one or more of the grounds listed in subsection (1), is unfair discrimination".

75 Towards New Collective Bargaining, wage and social protection strategies: Learning from the Brazilian Experience (Concept paper 2012 Cosatu) 39 available at http://www.cosatu.org.za/docs/discussion/2012/cec_concept paper.pdf (accessed 2012-08-27).

76 Antoine 2011 Comparative Labor Law \& Policy Journal 356. 
economy, ${ }^{77}$ within which worker exploitation and unsatisfactory employment conditions remain rife.

For South Africa 2012 in particular was a pivotal year as far as disputes over minimum wage levels were concerned. During mid-2012 miners at Lonmin mine in South Africa commenced strike action over demands for better working conditions and increased wages (the strike was also known as the Lonmin miners' strike or Marikana miners' strike). ${ }^{78}$ Central to the strike action was the view by workers that "... benefits of mining [we] re not reaching the workers or the surrounding communities. Lack of employment opportunities for local youth, squalid living conditions, unemployment and growing inequalities contribute[d] to this mess". ${ }^{79}$ The strike was riddled with violent incidents between members of the South African Police Services (SAPS), security personnel at the Lonmin mine, the leadership corps of the National Union of Mineworkers (NUM) and striking workers themselves. Headlines were made when weeks of unrest culminated in the death of approximately 47 individuals, of whom some 34 were striking mineworkers shot by police officers during a spurge of violence that took place on 16 August 2012.

The latter part of 2012, continuing into early 2013, also saw widespread strike action in the agricultural sector. This industrial action resulted in minimum wage levels for farm workers increasing just over $52 \%$ with effect from 1 March $2013 .{ }^{80}$ This was achieved through the amendment of Sectoral Determination 13: Farm Worker Sector. ${ }^{81}$ In response to the significant increase in minimum wages farmers and farmers' organisations alike criticised government for failing to consider the impact that these substantial increases might practically have on the farming industry, especially in the long run. It was argued that most farmers would not be able to afford the payment of wages at the new minimum wage levels rates, as a result of which many farmers would have to resort to lay-offs of workers in an attempt to remain financially sustainable. Despite the aforesaid fears Cosatu, while welcoming the increase in minimum wage levels in principle, maintained that the

77 Antoine 2011 Comparative Labor Law \& Policy Journal 352.

78 The Lonmin owned mine where the strike took place is situated in the Marikana area near the town of Rustenburg, North West province, South Africa.

79 "Lonmin an example of exploitation" Business Report (2012-08-17) available at http://www.iol.co.za/business/companies/lonmin-an-exampleof-exploitation-1.1365221 (accessed 2013-02-21).

80 See discussion under 5.1 below, Sectoral Determination 13: Farm Workers Sector.

81 See the discussion in 5.1 below. The amended Sectoral Determination 13 can be accessed at http://www.labour.gov.za/DOL/legislation/sectoraldeterminations/sectoral-determination-13-farm-worker-sector (accessed on 2018-06-09). 
increased wage levels still did not constitute a living wage, ${ }^{82}$ and further argued that merely contributing a fear of job losses to a particular

minimum wage level was too simplistic in its approach. ${ }^{83}$ While this happened just over five years ago already, at the time of writing this article there was still no clear statistics which indicated any significant rise in unemployment levels in the agricultural sector since 2013.

\section{The Present: The Wage Regulation Regime in South Africa}

Entering an era of democracy after the first democratic elections of 1994 , South Africa adopted the Constitution of 1993 (Interim Constitution), followed by adoption of the Final Constitution of 1996. The Constitution rendered values underlying an open and democratic society, such as, human dignity, equality, and the advancement of human rights and freedoms, applicable to all individuals. ${ }^{84}$ The Constitution is the supreme law of South Africa against which all government actions and legislation are measured. Any law or conduct inconsistent with the values enshrined in the Constitution is invalid, ${ }^{85}$ and may consequently be declared unconstitutional. $^{86}$ There is no single area of law in South Africa that remains unaffected by constitutional principles. All labour law and employment-related issues must therefore be considered in light of constitutional principles, specifically the Bill of Rights.

Section 39(1)(b) of the Constitution stipulates that "[w]hen interpreting the Bill of Rights, a court, tribunal or forum ... must consider international law ...". Similarly, section 233 holds that "[w]hen interpreting any legislation, every court must prefer any reasonable interpretation of the legislation that is consistent with international law over any alternative interpretation that is inconsistent with international

82 COSATU cautiously welcomes increase in farm workers minimum wage available at http://www.cosatu.org.za/show.php?ID = 6912 (accessed 201302-21)

83 COSATU cautiously welcomes increase in farm workers minimum wage available at http://www.cosatu.org.za/show.php?ID = 6912 (accessed 201302-21). See also "Wage Increase Farm Workers Sector - March 2013" LabourNet (2013-02-11) available at http://industrialrelations.labournet.com/ article-display/wage-increase-farm-workers-sector-\% E2 \% $80 \%$ 93-march2013/149 (accessed 2013-02-21); "Farm worker minimum wage increased $52 \%$, layoffs expected" Farmer's Weekly (2012-02-05) available at http:// www.farmersweekly.co.za/news. aspx?id $=35156 \& \mathrm{~h}=$ Grain-SA-advisesmembers-to-avoid-retrenchment-of-farm-workers (accessed 2013-02-21).

84 Constitution s 1. S 2 of the Constitution further states that the Bill of Rights “... enshrines the rights of all people in our country ...".

85 Constitution s 2.

86 Govindjee \& Van der Walt in Van der Walt et al (eds) Labour Law in Context (2012) 3 . 
law" 87 Since South Africa is a member state to the ILO, when considering minimum wages in South Africa in light of international law, the ILO's Decent Work Agenda is of great importance. Furthermore, in 2015 South Africa also ratified the United Nations International Covenant on Economic, Social and Cultural Rights. ${ }^{88}$ This Covenant includes the right of all individuals to an adequate standard of living. ${ }^{89}$

Section 23 of the Constitution remains the empowering provision as far as labour relations are concerned. Section 23(1) affords everyone the right to equality and fair labour practices, regardless of race, gender, employment status, and so on. In summary, all workers are protected under section 23(1) of the Constitution, regardless of whether they find themselves working in the formal or informal economy. To give effect to the rights protected under section 23, the Labour Relations Act 66 of 1995 (LRA), the Basic Conditions of Employment Act 75 of 1997 (BCEA), and the Employment Equity Act 55 of 1998 (EEA), amongst others, were enacted.

The BCEA was promulgated " $[\mathrm{t}] \mathrm{o}$ give effect to the right to fair labour practices referred to in section 23(1) of the Constitution by establishing and making provision for the regulation of basic conditions of employment; and thereby to comply with the obligations of the Republic as a member state of the International Labour Organisation; and to provide for matters connected therewith". 90 As far as wages as a basic condition of employment are concerned, the BCEA addresses issues such as the calculation and payment of remuneration, availability of remuneration information, permitted deductions from remuneration, and payment of benefit fund contributions. ${ }^{91}$ The BCEA in itself does not, however, provide for minimum wage levels and simply stipulates that an employee's wage should be calculated by reference to the number of hours ordinarily worked by the employee. ${ }^{92}$ However, in terms of section 51(1) of the BCEA the Minister of Labour was vested with the power to promulgate sectoral determinations aimed at establishing basic conditions of employment for employees in a particular sector and area.

Essentially there are three ways through which minimum wages (as well as other conditions of employment) may be set in South Africa. The first is by way of an agreement concluded in the workplace between the

87 See also National Union of Metal Workers of South Africa \& Others $v$ Bader Bop (Pty) Ltd \& Another 20032 BCLR 182 (CC) 37 where the Constitutional Court held that an interpretation that takes into account principles contained in relevant ILO Conventions is to be preferred.

88 Available at http://www.ohchr.org/EN/ProfessionalInterest/Pages/CESCR. aspx (accessed 2018-06-09).

89 "A national minimum wage is a powerful tool to break the poverty cycle" Mail \& Guardian (2016-12-12) available at https://mg.co.za/article/2016-1212-00-a-national-minimum-wage-is-a-powerful-tool-to-break-the-povertycycle (accessed 2018-06-09).

90 Preamble to the BCEA.

91 Ss 32 to 35 BCEA.

92 S 35(1) BCEA. 
employer and its employees, or between the employer and a specific employee (typically through a contract of employment). Secondly, collective agreements in terms of which identified employees, or employees as a group within an identified sector or industry, are provided with agreed working conditions may be concluded in any bargaining council. ${ }^{93}$ Thirdly, sectoral determinations in accordance with section 51(1) of the BCEA, or other ministerial determinations in accordance with section 50 of the BCEA and section 44 of the LRA, may be promulgated by the Minister of Labour. ${ }^{94}$ To date eleven sectoral determinations have been implemented in South Africa in terms of section 51(1) of the BCEA. The relevant sectors are farm workers, children in the performing arts, civil engineering, contract cleaning, domestic workers, forestry, hospitality workers, learnerships, private security, taxi industry, and wholesale and retail.

Late in 2017 the National Minimum Wage Bill of 2017 was introduced by the Minister of Labour's Office in the National Assembly. The Bill was introduced with a view to provide for an across-the-board national minimum wage, and the establishment of a national Minimum Wage Commission. The initial date for implementation of the Bill by the Precedency was earmarked as 1 May 2018, which did not materialise. The Bill was however passed by Parliament during the last week of May, and it is arguably only a matter of time before the Bill is signed off as legislation by the President. Though there are some exceptions and transitional provisions, in general the Bill sets out to implement a national minimum wage of R20 per hour. Not surprisingly the Bill has met with much resistance - both from employers and trade unions. Unions are rejecting implementing a national minimum wage at levels below minimum wages already set in sectoral determinations. A detailed discussion of the Bill, including arguments supporting and opposing the Bill as it stands, falls beyond the scope of this article. It will however be interesting to keep abreast of developments around the proposed Bill over the months to come.

\section{The Future: Options For a Legislated Minimum Wage System}

The justification for adopting a legislated minimum wage system, as opposed to a system of freely-determined wages, has historically been questioned in countries with an established culture of self-regulation, such as centralised bargaining. Over the past few years many of these countries have however shifted the method of wage-determination towards that of regulation. Such a shift in approach has largely been ascribed to increased undermining of, and loss of faith in, centralised

93 S 49 BCEA.

94 Ss 51 to 58 BCEA. 
bargaining, and the growing number of vulnerable workers exploited outside a formal system of employment regulation. ${ }^{95}$

As previously mentioned, any debate in South Africa around selfregulation or regulation through, for instance legislation, has now become mostly academic in nature. Minimum-wage levels have already been legislated for years in different sectors through sectoral determinations. And the recently-adopted National Minimum Wage Bill is a further definite step towards a system of legislated minimum wages. It is therefore no longer a question of whether minimum wages should be legislatively regulated, but rather how such wages could be best regulated through legislative measures. However, establishing a successful and practical system to legislatively regulate minimum wages, whether at national or sectoral level, is not a simple task. Whilst remaining sensitive to the plight of workers, particularly those earning at the lowest wage levels, there are many variables to consider, both from economic and legal perspectives, all of which might impact on the long-term consequences of minimum wage levels.

It is clear from the discussion earlier that the effect legislated minimum wage levels might have on unemployment rates remains uncertain and a topic for debate. It is argued that there are many reasons to expect minimum wages to have very little impact on employment levels in emerging economies such as South Africa, for various reasons. The first is that, in economies characterised by high levels of inflation, it might be very difficult to increase the real value of any legislated minimum wage. ${ }^{96}$ A second, yet more disturbing, reason is that the level of compliance with legislated minimum wages is frequently very low in developing countries. ${ }^{97}$ This may be as a result of minimum wages being set too high, ${ }^{98}$ the system for regulation being too complex, ${ }^{99}$ the absence of enforceable sanctions for non-compliance, or minimum wages levels simply not enforced as a result of factors such as a lack of resources. ${ }^{100}$

95 Cosatu 201244 available at http://www.cosatu.org.za/docs/discussion/2012/ cec_conceptpaper.pdf (accessed 2012-08-27).

96 Lustig \& McLeod Minimum Wages and Poverty in Developing Countries: Some Empirical Evidence (Discussion Paper 1997 International Economics).

97 Bhorat, Kanbur \& Mayet "Minimum Wage Violation in South Africa" 2012 International Labour Review 277.

98 Saget "Fixing minimum wage levels in developing countries: Common failures and remedies" 2008 International Labour Review; Lee \& Sobeck "Low-Wage Work: A Global Perspective" 2012 International Labour Review 141; Rani, Belser, Oelz \& Ranjbar "Minimum Wage Coverage and Compliance in Developing Countries" 2013 International Labour Review 381.

99 Rani, Belser, Oelz \& Ranjbar 2013 Int'l Lab. Rev.

100 Broecke, Forti, Vandeweyer The effect of minimum wages on employment in emerging economies: a literature review 2 available at http://national minimumwage.co.za/wp-content/uploads/2015/09/0221-Effect-of-Minimum -Wages-on-Employment-in-Emerging-Economies-A-Literature-Review.pdf (accessed 2018-06-09). 
Studies on minimum wages internationally suggest that more often than not criteria for determining minimum wages are largely economically driven. The most common economic criteria encountered in such studies, in order of relevance based on their inclusion in studies, include: inflation and the general cost of living; prevailing economic conditions in the country involved; existing wage levels; workers' needs; productivity; employment rate; capacity of businesses to pay minimum wages; and the availability of social security benefits to employees. ${ }^{101}$ Some interesting observations may be made from the above. Firstly, it is interesting, albeit alarming, to note that the needs of workers as a factor to determine minimum wage levels only ranks fourth in relevance. Secondly, the ability ${ }^{102}$ of businesses to actually afford the payment of minimum wages only ranks second to last. It is consequently of some concern that criteria directly influenced by worker and business considerations and needs are not regarded as top criteria in determining minimum wage levels.

Implementing any legislated minimum wage system notably involves two key issues for consideration: firstly, the approach to be used in implementing a legislated minimum wage and, secondly, the level at which minimum wages should be set. Turning to the first issue, there are several options for implementing legislated minimum wages. ${ }^{103}$ The most commonly observed approaches include: an across-the-board single national minimum wage; sector-specific minimum wages, ie, specific minimum wages determined for specific sectors or industries; or a combination of the aforesaid two approaches. Very few countries to date have opted for the implementation of a singular national minimumwage level. ${ }^{104}$ In countries where minimum-wage levels have been implemented on sectoral basis, two principal methods for establishing wage levels have emerged: wage levels as set by government itself, or wage levels concluded through collective bargaining between various stakeholders.

Turning to the second issue for consideration, ie, the level at which minimum wages should be set, it is generally agreed that a balance must

101 Eyraud \& Saget The Fundamentals of Minimum Wage Fixing (2005 ILO) 29

102 One must off course remain mindful of how such ability to afford is actually measured. Care should be taken in simply accepting arguments of ability or otherwise where the ability is based on any employer's subjective view on affordability. Also, wages only forms but one category in a range of possible expense categories when considering the issue around ability to afford.

103 For detailed discussions on examples of minimum wage systems implemented in various countries, see Broecke, Forti, Vandeweyer The effect of minimum wages on employment in emerging economies: a literature review available at http://nationalminimumwage.co.za/wp-content/uploads/ 2015/09/0221-Effect-of-Minimum-Wages-on-Employment-in-Emerging-

Economies-A-Literature-Review.pdf (accessed 2018-06-09) as well as Rani, Belser, Oelz \& Ranjbar 2013 Int'l Lab. Rev. Deakin 2017 ILJ also discusses the move in the UK from a system of sectoral collective bargaining to a legally binding national minimum wage, which is similar to the position SA currently finds itself in.

104 Eyraud \& Saget The Fundamentals of Minimum Wage Fixing (2005 ILO) 7. 
be reached between, on the one hand, setting minimum wages at levels which have the ability to meaningfully improve the livelihoods of workers, and, on the other hand, guarding against the creation of unsustainable minimum wage systems for a country's economy at large. ${ }^{105}$ Of critical importance however in deciding on any minimum wage level is moving towards setting minimum wages at levels which could be regarded as living wages. While some countries utilise a basic system within which a single, across-the board, national minimum wage is set, others have highly complex arrangements where minimum wages vary across regions, sectors, occupations and/or age groups. ${ }^{106}$ Up until such time as the National Minimum Wage Bill comes into effect South Africa is a good example of a highly complex system of sectoral determined wage levels. It is common for minimum wages in the affected sectors to vary by occupation, location, and hours of work within. Some commentators in fact view South Africa as being one of the countries with the most complex minimum wage system. ${ }^{107}$ This is rather interesting when considering studies which suggest that countries with a general national minimum wage system experience higher compliance rates when compared to countries that have numerous sectoral or occupational minimum wages. ${ }^{108}$

Those in favour of a legislated national minimum wage policy argue that a properly-assessed and implemented national minimum wage system can contribute towards reducing poverty and inequality, while potentially also boosting economic growth. It is consequently argued that a proper national minimum wage policy has an important role to play in building a more equitable and prosperous South Africa. The success of a national minimum wage policy however will be dependent on the implementation of other successful supporting policies. ${ }^{09}$

105 https://www.dailymaverick.co.za/article/2016-08-11-op-ed-a-national-mini mum-wage-for-south-africa-the-path-to-economic-growth/\#.WqUKgChuZdh (accessed 2018-06-09).

106 Broecke, Forti, Vandeweyer The effect of minimum wages on employment in emerging economies: a literature review 5 available at http://national minimumwage.co.za/wp-content/uploads/2015/09/0221-Effect-of-Minimum -Wages-on-Employment-in-Emerging-Economies-A-Literature-Review.pdf (accessed 2018-06-09).

107 "The most complex systems can be found in South Africa and India. In South Africa, minimum wage levels are set by sector, but these sector minimum wages can further differ by occupation, region, level of experience, firm size and hours worked" as held in Broecke, Forti, Vandeweyer The effect of minimum wages on employment in emerging economies: a literature review 5 available at http://national minimum wage.co.za/wp-content/uploads/2015/09/0221-Effect-of-Minimum -Wageson-Employment-in-Emerging-Economies-A-Literature-Review.pdf (accessed 2018-06-09).

108 Rani, Belser, Oelz \& Ranjbar 2013 Int'l Lab. Rev 402.

109 https://www.dailymaverick.co.za/article/2016-08-11-op-ed-a-national-mini mum-wage-for-south-africa-the-path-to-economic-growth/\#.WqUKgChuZdh (accessed 2018-06-09). 
A fundamental question South African policy-makers will therefore need to address is the nature of the relationship, if any, between a legislated national minimum-wage system and the existing system of sector-specific minimum wages set through sectoral determinations. ${ }^{110}$ International evidence suggests that legislated minimum wages work best when they operate in conjunction with arrangements providing for multi-employer collective bargaining, and should not be seen as a replacement for the latter. ${ }^{11}$ Approached from a broader policy perspective, the challenge is to find the best combination of policies and interventions which, together, will result in the creation of effective compliance strategies. ${ }^{112}$

\section{Conclusion}

Key issues that this article is hoped to have provoked some further thought on are: whether legislated minimum wage levels is a realistic and reasonable option, specifically in the South African context; whether the implementation of legislated minimum-wage levels could have a significant effect towards achieving the ILO's Decent Work Agenda; ${ }^{113}$ and the form a legislated minimum wage level system should adopt in order to have any chance at success.

As indicated there remains a clear divide between proponents advocating for minimum regulation and those who advocate for freedom of markets without unnecessary outside interference. Whilst there seems to be equally-valid arguments for both regulation and non-regulation, the general consensus internationally, at least at the time of writing this article, seems to be that the advantages of some form of regulation of minimum wages outweigh the risks or restrictions attached to such regulation.

It seems trite that an economy within which the financial position of the majority of citizens is constantly deteriorating is unlikely to do well in the long run. ${ }^{114}$ One cannot therefore ignore the advantages and disadvantages legislated minimum-wage policies could have on economies. Considerations around legislated minimum-wage levels took on a further level of complexity in face of the global financial crisis experienced in 2007/2008. During the early days of the crisis many governments opted for a recovery approach within which purchasing power and aggregate demand were maintained as key elements towards economic recovery. However, as the crisis increased in intensity, wage cuts as a result of both collective bargaining and unilateral cuts by

110 Deakin 2017 ILJ 24

111 Deakin 2017 ILJ 24.

112 Rani, Belser, Oelz \& Ranjbar 2013 Int'l Lab. Rev 399.

113 See the discussion of the ILO's decent work agenda in 4.1 above.

114 Stiglitz available at http://www.vanityfair.com/society/features/2011/05/topone-percent-201105 (accessed 2012-06-05). 
employers were increasingly observed, which resulted in an overall decline in wage levels and a resultant decline in aggregate demand. ${ }^{115}$

Issues of relevance to the ILO's Decent Work Agenda, such as providing a living wage, therefore continue to be prevalent, yet difficult to address. As a result, whilst basic economic theory predicates that the productivity of an industry should be a final consideration in wage determination, ${ }^{116}$ many unions argue for a return to social movement unionism. ${ }^{117}$ The concept of social movement unionism has been a topic of much research for years, and can generally be described as:

"a highly mobilized form of unionism which emerges in opposition to authoritarian regimes and repressive workplaces in newly industrializing countries of the developing world, and which is based in a significant expansion of semi-skilled manufacturing work. SMU is embedded in a network of community and political alliances, and demonstrates a commitment both to internal demographic practices as well as to the broader democratic and socialist transformation of authoritarian societies." 118

It might be argued that social movement unionism is in fact a key concept in the search for forward-thinking solutions as to how policy changes in the area of wage-determination could be set in motion and ultimately become successful. Social movement unionism asks, not only of trade unions as understood in labour law, but of a range of roleplayers, to address wider community issues such as education, skillsdevelopment, and employability. From a South African perspective, an on-going restraint in socio-developmental initiatives is the prevailing shortage of critical skills in many sectors. ${ }^{119}$ As example, trade unions, as part of social movement unionism, might therefore want to investigate how labour movements could possibly address these shortcomings. In short, social movement unionism not only concerns itself with employment rights and the organisation of workers, but rather engages in a far wider political struggle for the achievement of human rights, social justice and values that underpin any democratic society in general.

115 Labour Administrations and National Labour Policies: Current Challenges, Practices and Policies (2009 ILO Social Dialogue Sector) 10 available at http:/ /www.ilo.org/wcmsp5/groups/public/---ed_dialogue/---lab_admin/documents /publication/wcms_123787.pdf (accessed 2012-08-27).

116 Price \& Ho 2011 Comm. L. World Rev 110.

117 Return to Social Movement Unionism partner (2011 NALEDI) available at http: $/ /$ www.naledi.org.za/index. php?option $=$ com_k2\&view $=$ item\&id $=42$ : return-to-social-movement-unionism (accessed 2012-05-24).

118 Von Holdt "Social movement unionism: the case of South Africa" 2002 Work, Employment and Society 285.

119 Return to Social Movement Unionism partner (2011 NALEDI) available at http://www.naledi.org.za/index.php?option $=$ com_k2\&view $=$ item\&id $=42$ : return-to-social-movement-unionism (accessed 2012-05-24). The EEA defines designated groups to mean black people, women and people with disabilities, while black people is defined as a generic term which means Africans, Coloureds and Indians.

120 Cosatu 201141 available at http://www.cosatu.org.za/docs/reports/2011/ naledi_research_paper.pdf (accessed 2012-08-27). Also see discussion on 
Through issues highlighted in this article, yet without attempting to suggest any concrete recommendations or solutions, it seems as if any attempts to achieve overall living standards in line with a living wage ideal is likely only to be achieved through a combination of legal, economic and social movement interventions. As previously argued by Cosatu, actions to close the gap between minimum wage and living-wage levels should focus on core policy interventions aimed at, amongst others, (i) ensuring access to education, skills and human resource development aimed at redressing existing labour market deficiencies; (ii) access to cheap, reliable and safe public transport system(s); and, finally, (iii) the implementation of a national retirement scheme. ${ }^{120}$

Ultimately it seems to come down to the following question: Is it possible to introduce a system of legislated minimum wage levels which will have the power to provide employees with what could be regarded as, a living wage, without fuelling unemployment levels and impacting negatively on economic growth and job creation? ${ }^{121}$ As with many issues pertaining to law and economics, this is clearly not an easy question to answer, and there is definitely no blueprint (yet) for any successful system. In pursuing the ideal of social movement unionism, an economy requires collective action from different stakeholders, most notably governments investing in infrastructure, education and technology. ${ }^{122}$ It has therefore been said that regulation could be achieved not only through law in itself, but also through other mechanisms aimed at the achievement of social policy goals. Consequently, regulation should not only focus on specific sets of rules, but also on all state interventions and actions, as well as non-state social controls or influence, such as markets. 123

Perhaps the answer does not lie in a single, strictly-controlled system, but rather the implementation of an out-of-the-box strategy or strategies. Whilst developing such a clear one-size-fits-all minimum wage system model will undoubtedly be difficult, perhaps even impossible, a first step might be to investigate implementing an easily-adaptable system, and one which is firmly embedded in the below non-negotiable values and principles:

- Any minimum wage should be set at a level which, based on country specifics, would be regarded as a living wage;

- Minimum-wage levels must be set at levels which will not lead to a rise in unemployment levels;

- Economic growth and job creation should not be negatively impacted by the minimum-wage system and decided wage levels; and

social protection in Cosatu 201251 available at http://www.cosatu.org.za/ docs/discussion/2012/cec_conceptpaper.pdf (accessed 2012-08-27).

121 Price \& Ho 2011 Comm. L. World Rev 96.

122 Stiglitz available at http://www.vanityfair.com/society/features/2011/05/topone-percent-201105 (accessed 2012-06-05).

123 Baldwin \& Cave Understanding Regulation: Theory, Strategy and Practice 1999 as referenced in Benjamin 2. 
- Training and skills development of individuals should be a focal point in any minimum-wage system, which obligation should not be placed on the shoulders of individuals alone, but declared a shared obligation between individuals, employers and provincial and national government(s) alike.

It is hoped that this article has provided some valuable and clear insights into the multi-dimensional sphere and complexity of minimum wages and issues related thereto, and as such laid a basis from which more studies which could provide further insight into the topic might be undertaken. 